\title{
Estimation of Fatal Risks of Road Construction Workers in Occupational Accidents
}

\author{
Yol İnşaat İşçilerinin İş Kazalarına Bağlı Ölüm Risklerinin Tahmini
}

Atiye BíLiM (iD) , Osman Nuri ÇELIK

\begin{abstract}
Millions of people die every year because of fatal work accidents and diseases. When the accident rates of the construction industry in the world are analyzed, it is seen that these rates support the hazard situation of the sector. The construction sector is important for developing countries, but it also has a significant share, especially in fatal work accidents. Risks in the construction sector vary according to the project. Work accidents occurring in road construction have a significant share in the construction sector. In this study, 14910 work accident data in road constructions between 2013-2016 years are examined for Turkey. The parameters affecting the severity of the accident in the sector were determined. A score table was created in which road workers could determine their fatal risk. Thus, the results that contribute to the selection of employees suitable for the job and the adaptation process of the employee were derived.
\end{abstract}

Keywords: Construction, Fatal accidents, Road construction, Occupational safety, Work accidents.

\section{ÖZET}

Ölümcül iş kazaları ve hastalıkları nedeniyle her yıl milyonlarca insan ölmektedir. Dünyadaki inşaat sektörünün kaza oranları incelendiğinde, sektörün tehlike net bir șekilde görülmektedir. İnşaat sektörü gelişmekte olan ülkeler için önemli olmakla birlikte, ölümlü iş kazalarında da önemli bir paya sahiptir. İnşaat sektöründeki riskler projeye göre değişiklik göstermektedir. Yol yapımında meydana gelen iş kazaları inşaat sektöründe önemli bir paya sahiptir. Bu çalışmada, Türkiye 2013-2016 yılları arasında yol inşaatlarında gerçekleşen 14910 iş kazası verisi analiz edilmiştir. İlk olarak inşaat sektöründe kaza şiddetini etkileyen parametreler belirlenmiştir. Yol inşaatlarında çalışan işçilerin iş kazasına maruz kaldığında, ölüm riski seviyelerini tahmin eden bir skor tablosu geliştirilmiştir. Böylece, işverenlerin işe uygun çalışan seçimi ve çalışanın işe uyum sürecine katkı sağlayan sonuçlar türetilmiştir.

Anahtar Kelimeler: İnşaat, Ölümlü kazalar, Yol yapımı, İş güvenliği, İş kazaları.

Atiye BiLiM | abilim@ktun.edu.tr

Konya Teknik Üniversitesi, Teknik Bilimler Meslek Yüksekokulu, Konya, Türkiye

Konya Technical University, Vocational School of Technical Sciences, Konya, Turkey

Osman Nuri ÇELiK I oncelik@ktun.edu.tr

Konya Teknik Üniversitesi, Mühendislik ve Doğa Bilimleri Fakültesi, Konya, Türkiye

Konya Technical University, Faculty of Engineering and Natural Sciences, Konya, Turkey

“Bu çalışma Prof. Dr. Osman Nuri ÇELIK danışmanlığında Konya Teknik Üniversitesi Lisansüstü Eğitim Enstitüsü tarafindan 10.12 .2018 tarihinde tamamlanan "Karayolu ve Demiryolu İnşaatlarında Meydana Gelen İş Kazalarının Analizi ve Modellenmesi" başlıklı ve 534892 tez no'lu doktora tezinden türetilmiştir." 


\section{INTRODUCTION}

Work accidents, deaths, and injuries related to these accidents are at a worrying level globally. Work accidents are among the most significant health hazards in industries and are associated with high mortality, morbidity, spiritual damage, and economic losses in the world. Work accidents bring direct and indirect health services and economic burdens for communities. An accident causes physical, social, economic, and spiritual damages [1, 2]. Work accidents both significantly impact human integrity and impose high costs for a social security system [3]. The economic burden of insufficient occupational safety and health practices is estimated to be $4 \%$ of global Gross Domestic Product each year [4].

The construction sector is complicated in terms of working conditions. The construction industry is dynamic and dangerous due to construction workplaces and labor [5 -7]. Construction sites are often identified as unsafe and dangerous places $[8,9]$ Each construction project varies, and each type of project (eg a road or bridge) has its characteristics such as operating performance methods, materials, and construction techniques [10]. Variability of construction activities, variety of equipment causes uncontrolled human errors [11]. Therefore, work accident rates are quite high in this sector.

Considering the distribution of accidents resulting in an incapacity for three days and more in the EU by various sectors, it is seen that the construction sector is the first in all sectors [12]. According to EU-28 countries, the construction sector accounts for $11.3 \%$ of non-fatal work accidents and $20.1 \%$ of fatal work accidents. It is located in first place in the sectors for fatal work accidents [13].

Occupational safety is a problem to be considered for all construction sites. However, not all construction sites have the same type of hazards and accidents. In general, there are infinitely diverse and completely unidentifiable hazards and risks in the construction industry, and unique prevention methods must be taken and implemented according to the type of building to eliminate the risks [14].

Studies on road safety lacks due to the variety of construction and worksite environments [15]. The safety of road workspaces has been a public concern for many years, and great efforts have been made to alleviate traffic accidents in the work area [16-19]. Road works are difficult to isolate from the public, which blocks effective occupational health and safety controls [20]. Understanding the characteristics and underlying causes of accidents in road work areas is critical in developing effective safety measures in these areas [16]. Numerical values play an essential role in determining and evaluating the hazards in construction sites. Every work in the construction area should be examined with the workers to minimize workplace accidents and identify hazards correctly [21].

In the literature, risk assessment techniques used in assessing current hazards and risks in the workplace and taking precautions are classified into three categories as quantitative, qualitative, and mixed [22]. In the quantitative method, while the numerical values are given to the severity of the risk and the probability of the risk to occur, descriptive values such as low, high, and very high are used in the risk calculation in the qualitative method [23]. However, the mixed method includes both qualitative and quantitative methods.

There is no suitable risk analysis method for all workplaces. Occupational health and safety (OHS) experts will select the Risk Analysis method that will be most suitable for the workplace [24]. Risk analysis for sectors should not 
be only based on the personal perceptions of OSH experts. In this sense, academic studies are precious. Creating an objective and general risk assessment table for the sectors, supported by scientific facts, based on experienced work accidents, will be the most important step towards reducing work accidents. At the same time, these created tables will be an important guide for the OHS experts. In this study, the work accidents that occurred in road constructions and the workers exposed to the accident were analyzed, hazard and risk factors were identified for the sector. Equality is derived from which the worker can determine the risk of fatal if an accident occurs by utilizing workers' characteristics and working environment features in road construction. Workers in this sector will be able to identify their possibility of fatal accidents with this equality.

\section{MATERIAL AND METHODS}

Successful strategies for accident prevention will depend on the effective analysis of work accidents and cooperation with workers. By investigating root causes, dangerous conditions and unsafe behaviors can be identified [25].

Statistical data are important for the prevention of work accidents and a starting point for safety at work [26]. Analysis of work accident records provides a helpful way to identify patterns in accidents in professional populations. Work accidents are complex events in which many factors influence causality, and their prevention is only possible by analyzing past events and interpreting statistical results accurately [27]. Data on work accidents should be analyzed carefully because it is important to determine the priorities of occupational safety policies and get valuable tips [28]. If the causes of work accidents are known, the priority of possible prevention will be determined. Also, if there is any deficiency of the laws, they will contribute to the closure of these defects.
The share of total work-related accidents in Turkey in the construction sector for 2016 is $15.6 \%$, while its share in fatal work accidents is $35.3 \%$. So, about one-third of fatal work accidents in Turkey (1/3) are realized in the construction industry [29].

The construction sector in Turkey consists of three subactivities (Table 1). The construction activity where fatal work accidents occurred most frequently was the nonbuilding construction, including road constructions. For this reason, a detailed analysis of fatal work accidents is needed for this sector.

Table 1. Fatality work accident rates of construction sub-activity groups by 2012-2016.

\begin{tabular}{|c|c|c|c|c|c|c|}
\hline \multirow{2}{*}{$\begin{array}{l}\text { Classification of } \\
\text { Economic } \\
\text { Activity }\end{array}$} & \multicolumn{6}{|c|}{ *Accident Incidence Rate } \\
\hline & 2012 & 2013 & 2014 & 2015 & 2016 & Average \\
\hline $\begin{array}{l}\text { Building } \\
\text { Construction }\end{array}$ & 12.37 & 11.49 & 21.88 & 18.87 & 20.01 & 16.92 \\
\hline $\begin{array}{l}\text { Non-building } \\
\text { Construction }\end{array}$ & 20.96 & 31.12 & 42.23 & 34.01 & 35.24 & 32.71 \\
\hline $\begin{array}{l}\text { Specialized } \\
\text { Construction } \\
\text { Activities }\end{array}$ & 14.06 & 2.59 & 28.08 & 31.50 & 39.23 & 23.09 \\
\hline
\end{tabular}

* Number of work accidents per 100000 workers

Statistics of work accidents in Turkey are recorded by the Social Security Institution (SSI). Between 2013 and 2016, 14910 work accidents occurred in road constructions (Table 2). As seen in Table 2, both fatal and injured work accidents in the sector, unfortunately, tend to increase.

Table 2. Number of fatal and injured work accidents in road constructions.

\begin{tabular}{lccccc}
\hline $\begin{array}{l}\text { Work accidents in } \\
\text { road constructions }\end{array}$ & $\mathbf{2 0 1 3}$ & $\mathbf{2 0 1 4}$ & $\mathbf{2 0 1 5}$ & $\mathbf{2 0 1 6}$ & Total \\
\hline Fatal & 63 & 57 & 74 & 86 & 280 \\
Injured & 2677 & 3081 & 3748 & 5124 & 14630 \\
\hline Total & 2740 & 3138 & 3822 & 5210 & 14910 \\
\hline
\end{tabular}


This study aims to analyze 14910 work accidents occurring in the sector, to determine the factors affecting the accident severity (fatal or injury), and then to analyze 280 fatal work accident data in the light of these factors and to determine the fatal risk level of each worker in the sector.

14910 work accident data between 2013 and 2016 in road constructions were requested from SSI and provided. The information in the work accident notification form is organized and divided into categories as an independent variable. The selection of the independent variables was made considering the univariate frequency analysis and cross-tabulation results.

A dependent variable is a variable affected by other variables when the value of other variables changes. In an

Table 3. Independent variables.

\begin{tabular}{|c|c|}
\hline $\begin{array}{l}\text { Independent } \\
\text { variables }\end{array}$ & Category of independent variables \\
\hline Education status & $\begin{array}{l}\text { illiterate } \\
\text { Primary education } \\
\text { High School and above }\end{array}$ \\
\hline Occupation groups & $\begin{array}{l}\text { Managers } \\
\text { Professionals } \\
\text { Technicians and associate professionals } \\
\text { Clerical support, Service and sales workers } \\
\text { Craft and related trades workers } \\
\text { Plant and machine operators, and assemblers } \\
\text { Elementary occupations }\end{array}$ \\
\hline Age & $\begin{array}{l}<18 \\
18-30 \\
30-40 \\
\geq 40 \\
\end{array}$ \\
\hline Marital status & $\begin{array}{l}\text { Widowed } \\
\text { Divorced } \\
\text { Single } \\
\text { Married } \\
\end{array}$ \\
\hline Experience & $\begin{array}{l}<1 \text { year } \\
1-10 \text { year } \\
10-20 \text { year } \\
>20 \text { year }\end{array}$ \\
\hline OHS education & $\begin{array}{l}\text { OHS Training } \\
\text { No OHS training }\end{array}$ \\
\hline Working place & $\begin{array}{l}\text { Industrial site, workshop, factory } \\
\text { Office } \\
\text { Underground } \\
\text { Highway, transportation vehicles } \\
\text { Construction site }\end{array}$ \\
\hline Worked material & $\begin{array}{l}\text { Natural elements } \\
\text { Hand tools } \\
\text { Construction materials } \\
\text { Machinery and equipment } \\
\text { Vehicle }\end{array}$ \\
\hline
\end{tabular}

event examined, the affected variable is the dependent variable. Variables whose value is determined according to random conditions, which change independently and affect the change of other variables, are called independent variables [30].

In this study, accident severity (fatal or injury) was chosen as the dependent variable. Independent variables defined in the study are given in Table 3.

The categorically defined data set was transferred to the SPSS program and analyzed statistically using crosstabulation analysis.

The cross-tabulation analysis is defined as the analysis of two categorical variables (nominal or ordinal) simultaneously to determine whether there is an experimental relationship between them [31]. One of the aims of this study is to identify the independent variables related to the severity of the accident. Therefore, in this study, binary analysis was performed between the dependent variable and each independent variable defined with the help of crosstabulation analysis.

Cross-tabulation is a form of a matrix with a categorical variable in rows and a categorical variable in columns. For example, if it is desired to perform a binary analysis to interpret the relationship between a variable with A categories and another variable with B categories, cross-tabulation is performed with a matrix with $\mathrm{A} \times \mathrm{B}$ numbers. Each cell shows the frequency observed to the researcher, giving the frequency distribution of how one variable is distributed across each category in the other variable [32].

After cross-tabulation is established and frequency distribution in the cells occurs, the second step is to question the relationship between the variables. Pearson chi-square test is one of the tests used to interpret this relationship successfully [33]. The Pearson chi-square test compares the 
expected values with those observed if there was no relationship between the two variables [34]. In other words, the Pearson chi-square test is used to define the importance of the relationship between variables [35].

Several assumptions must be met before performing the Pearson chi-square test. For the test to be meaningful, each case must be in a cell in the cross-tabulation. The crosstab may have a maximum of $20 \%$ of cells with an expected frequency of less than 5; expected frequencies below 1 are unacceptable [36].

If the assumptions are met, the chi-square value can be calculated using Equation 1.

$$
\mathrm{x}^{2}=\sum_{i=1}^{n} \frac{\left(O_{i}-E_{i}\right)^{2}}{E i}
$$

$\mathrm{O}=$ frequency observed

$\mathrm{E}=$ Expected frequency

$\mathrm{n}=$ Number of samples

Pearson chi-square test hypothesizes that the variables in the row and column can be independent or dependent. The zero-hypothesis formulated within the scope of the study is as follows;

$\mathrm{H}_{0}=$ There is no relationship between the independent variable and the dependent variable (accident severity).

$\mathrm{H}_{1}=$ There is a relationship between the independent variable and the dependent variable (accident severity).

After calculating the Pearson chi-square value, the $\mathrm{p}$ value (which represents the significance of the chi-square value) based on this value should also be calculated, taking into account the degree of latitude. P-value is the probability value used to determine how the observed value deviates from the expected value by chance. Generally, if the Pvalue is less than $0.05, \mathrm{H}_{0}$ hypothesis is rejected, and it is assumed that there is a relationship between the variables. The degree of latitude is calculated with Equation 2.

$\mathrm{df}=($ Number of columns -1$) \mathrm{x}($ Number of rows -1$)$

As a result of the cross-tabulation analysis, it was found that the variables of;

- Education

- Occupation

- Age

- Marital status

- $\quad$ Experience

- $\quad$ OHS training and

- $\quad$ The place of the accident

- The material causing the accident significantly affected the severity of the accident.

The independent variable with the highest degree of impact is determined as the worked material (Table 4).

Table 4. Cross tabulation analysis results.

\begin{tabular}{lll}
\hline Independent variables & \multicolumn{2}{c}{ Pearson's $X^{2}(d f), p$} \\
\hline Education status & $X^{2}(2)=20.034$ & $P=0.018$ \\
Occupation groups & $X^{2}(6)=35.772$ & $P=0.000$ \\
Age & $X^{2}(3)=79.697$ & $P=0.000$ \\
Marital status & $X^{2}(3)=14.229$ & $P=0.005$ \\
Experience & $X^{2}(3)=54.825$ & $P=0.000$ \\
OHS education & $X^{2}(1)=33.139$ & $P=0.000$ \\
Working place & $X^{2}(4)=97.670$ & $P=0.000$ \\
Worked material & $X^{2}(4)=128.713$ & $P=0.000$ \\
\hline
\end{tabular}

Quantitative risk assessment methods use numerical methods to calculate risk. In quantitative risk analysis, numerical values are given to values such as the probability of a dangerous event, the effect of the hazard, and mathematical and logical methods process these values, and the risk value is found [23]. That is, the risk value can be calculated with the formula in Equation 3. 
Risk $=$ Possibility of a Hazard Event $\mathrm{x}$ Impact of Hazard (3)

280 fatal work accidents occurring in road constructions between 2013 and 2016 were examined in terms of independent variables that were found to impact the severity of accidents. The frequencies of each variable were determined according to the subcategories given in the tables. The subcategory with the highest frequency value was assumed to be 100 , and coefficient values were calculated for the others by the proportioning method. For these variables, the impact value was determined according to the Pearson chi-square values obtained from the crosstabulation analysis (Table 5). According to the results, for the fatal risk, Table 5 was created below.
To calculate the fatal risk score, the frequency of that category is multiplied by the impact value of that category. This process is done for each category, and the results are added. Equation 4 is derived as follows.

Fatal Risk Score $=$ Education Status Frequency x 0.04 + Occupation Groups Frequency x 0.08 + Age Frequency x 0.17+ Marital Status Frequency x $0.03+$ Experience Frequency x 0.12 + OHS Education Frequency x $0.07+$ Working Place Frequency x $0.21+$ Working Material Frequency x 0.28

Fatal risk scores were calculated for each of the 280 fatal accident data. Table 6 was created according to score

Table 5. Probability and impact value of variables to determine fatal risk.

\begin{tabular}{|c|c|c|c|}
\hline Risk criteria & Subcategories & Frequency & Impact Value (\%) \\
\hline \multirow{3}{*}{ Education status } & Illiterate & 0 & \multirow{3}{*}{4} \\
\hline & High School and above & 33 & \\
\hline & Elementary school & 100 & \\
\hline \multirow{7}{*}{ Occupation groups } & Managers & 1 & \multirow{7}{*}{8} \\
\hline & Professionals & 9 & \\
\hline & Clerical support, Service and sales workers & 9 & \\
\hline & Technicians and associate professionals & 21 & \\
\hline & Craft and related trades workers & 85 & \\
\hline & Elementary occupations & 96 & \\
\hline & Plant and machine operators, and assemblers & 100 & \\
\hline \multirow{4}{*}{ Age } & $<18$ & 0 & \multirow{4}{*}{17} \\
\hline & $18-30$ & 40 & \\
\hline & $30-40$ & 42 & \\
\hline & $\geq 40$ & 100 & \\
\hline \multirow{4}{*}{ Marital status } & Widow & 0 & \multirow{4}{*}{3} \\
\hline & Divorced & 7 & \\
\hline & Single & 27 & \\
\hline & Married & 100 & \\
\hline \multirow{4}{*}{ Experience } & $<1$ year & 5 & \multirow{4}{*}{12} \\
\hline & 10-20 year & 37 & \\
\hline & $1-10$ year & 60 & \\
\hline & $>20$ year & 100 & \\
\hline \multirow{2}{*}{ OHS education } & OHS education & 0 & \multirow{2}{*}{7} \\
\hline & Non-OHS education & 14 & \\
\hline \multirow{5}{*}{ Working place } & Industrial site, workshop, factory & 2 & \multirow{5}{*}{21} \\
\hline & Office & 2 & \\
\hline & Underground & 5 & \\
\hline & Highway, transportation vehicles & 53 & \\
\hline & Construction site & 100 & \\
\hline \multirow{5}{*}{ Working material } & Natural elements & 4 & \multirow{5}{*}{28} \\
\hline & Hand tools & 4 & \\
\hline & Construction materials & 15 & \\
\hline & Machinery and equipment & 29 & \\
\hline & Vehicle & 100 & \\
\hline
\end{tabular}


distributions. Thus, it is possible to determine the fatal risk level. Workers with a fatal risk score of 60 or higher were identified in the high-risk group, workers with a score of 40-60 were in the medium-risk group, and workers with a score of less than 40 were in the low-risk group [37].

Table 6. Fatal risk scores of workers.

\begin{tabular}{ccc}
\hline Fatal risk score & Fatal risk level & Risk priority \\
\hline$>60$ & High & 1 \\
$40-60$ & Medium & 2 \\
$<40$ & Low & 3 \\
\hline
\end{tabular}

Equality 4 and Table 6 were created due to four-year work accident data analysis, tested on new work accident data. For this purpose, 91 fatal work accident data in 2017 in road constructions were provided from SSI. The fatal risk score of each worker was calculated. As a result of the calculations, it was concluded that $88 \%$ of the fatal work accidents in the sector were in the high and medium risk group (Figure 1). In other words, the estimated power of the derived equation is $88 \%$, which means that if protective measures were taken for the workers in the high and medium risk group by applying the derived equation on the workers and determining their risk scores, $88 \%$ of the work accidents in the sector would have been prevented.

Figure 1. Workers' fatality risk scores according to equation 4 by the year 2017 .

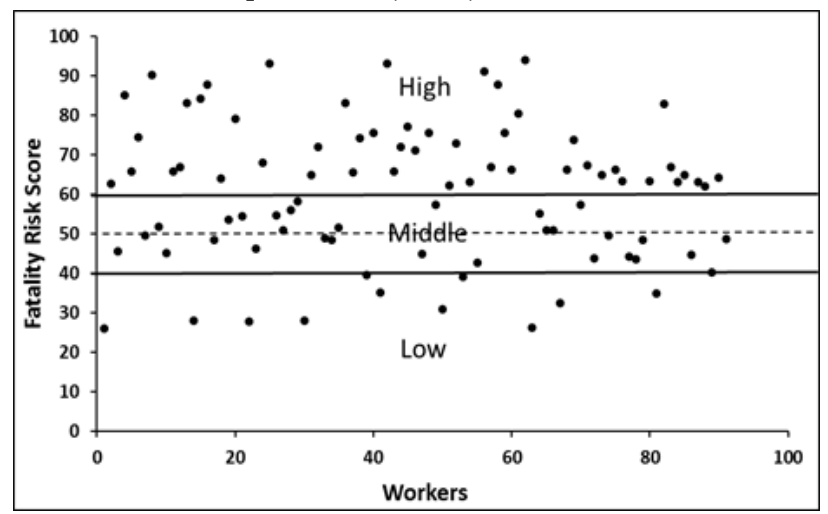

\section{RESULTS}

The construction industry in the world has an important share especially in the number of fatal work accidents. Risks in the construction sector differ according to the project. The share of total work accidents in Turkey in the construction sector for 2016 is $15.6 \%$, the share of fatal work accidents is $35.3 \%$. So, about one-third of fatal work accidents in Turkey (1/3) are realized in the construction industry. The construction activity where fatal work accidents occur most is "Nonbuilding Construction," which includes road construction. Therefore, the need for a detailed examination of work accidents in this sector has emerged for occupational safety.

Data of 14910 work accidents that occurred in road constructions between 2013 and 2016 were analyzed. It has been determined that the educational status, occupation, age, marital status, experience, OHS training of the worker, the location of the accident, and the working material causing the accident significantly affected the severity of the accident. The variable that most affected accident severity was determined as the working material.

280 fatal accidents occurred in the four years. When these fatal accidents in road constructions between 20132016 were examined in line with the parameters determined to affect the severity of the accident, it was concluded that the occupational group in which the fatal accident occurs is 'Plant and machine operators, assemblers'. Fatal accidents are the highest among workers aged 40 and over, married workers, and workers with more than 20 years of experience. It was observed that the number of fatal accidents increased as the age and experience of workers increased. The material causing the fatal accidents was the vehicles. Fatal accidents related to machinery and equipment took place secondly. 
A fatal risk score equation was derived for road construction workers by using work and worker characteristics. Enterprises will be able to determine whether they have workers with a high risk of fatal. They will also consider this situation in risk analysis. It will be very beneficial for the sector in order to prevent fatal work accidents.

\section{CONCLUSIONS}

The critical point in occupational safety is to take precautions before a work accident occurs. Therefore, this fatal risk score equation allows the sector to produce proactive solutions for occupational safety. Even the workers in the industry can easily use this equality and determine their fatal risk. Thus, workers with high risk will continue to work more carefully and precisely. Enterprises will also know the fatal risk of each worker if their current employment is in a work accident. It will contribute significantly to the planning of the control and improvement precautions.

In terms of enterprises, it also provides security in the selection of new workers. For example, if the worker plans to hire a machine operator, a younger worker can be recruited, as the impact of the age factor on accident severity has been identified, resulting in a low fatal risk.

Equality reflects the state of the sector, as it has been achieved by investigating work accidents. The data obtained from the study are free from personal thought or perception and are completely based on scientific supports. Therefore, OHS experts will have made a more realistic risk analysis by adding the workers' risk levels to their risk analyses. Safety precautions will take priority in workers who have high-risk levels. The equality of fatal risk score achieved in the study aims to contribute to both enterprises and the country's economy by reducing fatal work accidents in the sector.
The proactive approach to risk analysis in OHS is based on the principle of predicting risks, reducing them, or eliminating them before a work accident has occurred. The fatal risk equality derived from the study will also provide the opportunity to produce proactive solutions for the sector. The workers in the sector will have the chance to determine own fatal risk levels with this method easily. Companies can easily calculate these scoring values for their workers and determine whether they have workers at risk of fatal in a work accident and if so, they can determine the risk levels of these workers and develop protection policies for them. Thus, they can reduce the probability of a fatal work accident. Not only environmental factors taken into consideration when performing risk analyzes, but also whereas the demographic characteristics of the workers in the sector are effective in work accidents. Therefore, considering these factors, the risk assessment will be more realistic and proactive.

Although the equality developed as a result of the study is for road constructions, the methodologies realized in this study can be applied to different sectors, and similar equations can be derived for other sectors. It will also enable improvements in occupational safety policies for sectors.

Author Contributions : In the scope of this study, first author contributed to the formation of the idea, literature review, obtaining the results and writing. Second author contributed to the formation of the idea, literature review, obtaining and evaluating the results and reviewing the manuscript.

Conflict of Interest: There is no conflict of interest with any person / institution in the article prepared.

Financial Support: No financial support was received from any person, institution or organization in this study. 
Ethical Approval: There is no need to obtain permission from the ethics committee for the article prepared.

\section{REFERENCES}

[1] Prieskop FG. "Occupational Safety. In: Joseph LaDou”. ed., in Current occupational and environmental medicine, 4th ed. New York, McGraw Hill, p. 609, 2007.

[2] Abbasianjahromi H, Etemadi A. "Applying social network analysis to identify the most effective persons according to their potential in causing accidents in construction projects". International Journal of Construction Management, p. 1-14, 2019.

[3] Macedo AC, Silva IL. "Analysis of occupational accidents in Portugal between 1992 and 2001". Safety Science, 43(5-6), p. 269-286, 2005.

[4] International Labour Organization (ILO). "Safety and Health at Work". https://www.ilo.org/global/ topics/safety-and-health-at-work/lang--en/index.htm (19.05.2021).

[5] Kines P. "Construction workers' falls through roofs:: Fatal versus serious injuries". Journal of Safety Research, 33(2), p. 195-208, 2002.

[6] Hallowell MR, Gambatese JA. "Construction safety risk mitigation". Journal of Construction Engineering and Management, 135(12), p. 1316-1323, 2009.

[7] Al-Tabtabai HM. "Analyzing construction site accidents in Kuwait”. Kuwait J. Sci. Eng, 29(2), p. 213238, 2002.

[8] Elsebaei M, Elnawawy O, Othman A, Badawy M. "Causes and impacts of site accidents in the Egyptian construction industry". International Journal of Construction Management, p. 1-12, 2020.

[9] Sherratt F, Farrell P, Noble R. "UK construction site safety: discourses of enforcement and engagement". Construction management and economics, 31(6), p. 623-635, 2013.

[10] Lingard H, Rowlinson S. "Occupational health and safety in construction project management". 1st ed., London, Routledge, p.396, 2004.

[11] Al-Humaidi H, Tan FH. "Construction safety in Kuwait". Journal of Performance of Constructed Facilities, 24(1), p. 70-77, 2010.

[12] Gürcanli GE. "Dünyada ve Türkiye’de İş Güvenliğinde Gelinen Durum ve İnşaat Sektörü”. TMMOB Ölçü Dergisi, Şubat sayısı, p. 90-99, 2008.
[13] Eurostat, European Statistics on Accidents at Work (ESAW). Statistical Office the European Union, 2016.

[14] Nazlığlu A. "İnşaat Sektöründe Kullanılan Kule Vinçler ile Yapılan Çalışmalarda Karşılaşılan Risklerin Tespiti ve Korunma Yolları”. Çalışma ve Sosyal Güvenlik Bakanlığı, İş Sağlığı ve Güvenliği Genel Müdürlüğ̈̈, Ankara, Türkiye, p. 118, 2014.

[15] Kim YA, Ryoo BY, Kim YS, Huh WC. "Major accident factors for effective safety management of highway construction projects". Journal of Construction Engineering And Management, 139(6), p. 628640, 2012.

[16] Bai, Y, Li Y. "Determining Major Causes of Highway Work Zone Accidents in Kansas". Kansas Department of Transportation, University of Kansas Center for Research, Phase II. 2007.

[17] Garber NJ, Zhao M. Final report crash characteristics at work zones. Virginia Department of Transportation, the University of Virginia, Scientific Report, Rep. No. VTRC 02-R12, 2002.

[18] Pigman J, Agent K. Highway Crashes in Construction and Maintenance Work Zones. Transportation Research Record, 1270, 1990.

[19] Pal R, Sinha K.C. "Analysis of Crash Rates at Interstate Work Zones in Indiana". Transportation Research Record: Journal of the Transportation Research Board, 1529(1), p. 43-53, 1996.

[20] Debnath AK, Banks T, Blackman R, Dovan N, Haworth N, Biggs H. "Beyond the barriers: Road construction safety issues from the office and the roadside". Paper accepted for presentation at the 5th International Conference on Applied Human Factors and Ergonomics, 19-23 July, Kraków, Poland, 2014.

[21] Uslu M. 6331 nolu İş Sağlı̆̆ı ve Güvenliği Kanunu İnşaat sektöründe değerlendirilmesi ve Şantiyelerde Risk Değerlendirilmesi, Sağllk Bilimleri Enstitüsü, Yıldız Teknik Üniversitesi, İstanbul, Türkiye, 2014.

[22] Marhavilas PK, Koulouriotis D, Gemeni V. "Risk analysis and assessment methodologies in the work sites: On a review, classification and comparative study of the scientific literature of the period 20002009". Journal of Loss Prevention in the Process Industries, 24: p. 477-523, 2011.

[23] Ceylan H, Başhelvacı VS. "Risk değerlendirme tablosu yöntemi ile risk analizi: Bir uygulama”. International Journal of Engineering Research and Development, 3(2), p. 25-33, 2011.

[24] Erzurumluoğlu K, Köksal KN, Gerek İH. "İnşaat 
Sektöründe Fine-Kinney Metodu Kullanılarak Risk Analizi Yapılması". 5. İşçi Sağlığı ve İş Güvenliği Sempozyumu, TMMOB İnşaat Mühendisleri Odası: İzmir. p. 137-146, 2015.

[25] Unsar S, Sut N. "General assessment of the occupational accidents that occurred in Turkey between the years 2000 and 2005". Safety Science, 47(5), p. 614619, 2009.

[26] Hämäläinen P, Saarela KL, Takala J. “Global trend according to estimated number of occupational accidents and fatal work-related diseases at region and country level”. Journal of safety research, 40(2), p. 125-139, 2009.

[27] Dizdar EN, Kurt M. "A Rule-Based System Approach For Safety Management In Hazardous Work Systems". Pamukkale University Journal of Engineering Sciences, 4(3): p. 743-747, 1998.

[28] Lortie M, Rizzo P. "The classification of accident data”. Safety Science, 31(1), p. 31-57, 1998.

[29] Bilim A, Çelik ON. “Türkiye’deki İnşaat Sektöründe Meydana Gelen İş Kazalarının Genel Değerlendirmesi”. Ömer Halisdemir Üniversitesi Mühendislik Bilimleri Dergisi, 7(2), p. 725-731, 2018.

[30] Mutlu M. Açık İşletme Kömür Madenciliğinde Lojistik Regresyon Analizi İle İş Kazalarının Değerlendirilmesi, Yüksek Lisans Tezi, Fen Bilimleri Enstitüsü, Osmangazi Üniversitesi, Eskişehir, Türkiye, p. 123, 2013.

[31] Babbie ER. The basics of social research. 2013: Cengage Learning.

[32] Kazan EE. Analysis of fatal and nonfatal accidents involving earthmoving equipment operators and onfoot workers, PhD Thesis, Wayne State University, p. 173, 2013.

[33] Sims, R.L., Bivariate data analysis: A practical guide. 2000: Nova Publishers.

[34] Elliott AC, Woodward WA. Statistical analysis quick reference guidebook: With SPSS examples, Sage, 2007.

[35] Cakan H. Analysis and modeling of roofer and steel worker fall accidents, PhD Thesis, in Civil and Environmental Engineering, Wayne State University, p. 156, 2012.

[36] Fields A. Discovering statistics using SPSS, 2nd ed., US: Sage Publications, 2005.

[37] Bilim A. Karayolu ve Demiryolu İnşaatlarında Meydana Gelen İş Kazalarının Analizi ve Modellenmesi, Doktora tezi, in Fen Bilimleri Enstitüsü, İnşaat Mü- hendisliği Anabilim Dalı, Selçuk Üniversitesi, Konya. p. 167, 2018. 